\title{
'I am not made of stone': Theatrical Revision of Gesture in Shakespeare's Plays
}

STEVEN URKOWITZ

F or the last few months I've been looking for familiar and preeminently visible body-language coded by Shakespeare in the scripts of his plays. I've been finding hundreds of instances of a highly articulate vocabulary of gesture he choreographs for his actors so that they in turn can express more dimensions of recognizable human experience to his audiences.

Most of the actions Shakespeare calls for are relatively easy to find once you decide to look for them. You get what you can from the formal stage directions, of course, and then you hunt for the cues embedded in the dialogue as instructions: 'Give me your hand,' 'Take this purse,' or 'Let us go.' Very soon you start to notice just how much attention Shakespeare pays to the mechanics of gesture and the subtle stylistics of moving actors around and on and off the relatively empty platform stages of the English Renaissance.

But the great surprise for me in these last few months of reading has been seeing just how much of what we call 'character' itself can be determined or altered in a Shakespearean script by changing a movement, or by altering the direction in which a line is spoken, or by assuming a different physical alignment towards other character on stage.

I've found the most interesting evidence in those plays which were first printed in versions radically different from those we are most familiar with now: the earlier and later quartos and First Folio editions of Hamlet, King Lear, Richard III, Henry V, Merry Wives of Windsor, Romeo and Juliet and the Second and Third Parts of Henry VI.

For the last fifty to eighty years, people haven't looked very closely at the differences of physical gesture called for in the alternative scripts of these plays. For several reasons, all of which are currently under attack, the earlier versions of these plays were labelled 'bad' quartos. The orthodox story about 'bad' quartos is that Shakespeare didn't write 
them. Rather, it is fashionable to argue that an anonymous piratical actor or string of actors who had played small roles in Shakespeare's company memorized as much as they could of the plays as they heard them. Then they wrote out all they could recall, confusing and botching up whatever they couldn't remember precisely, and then they sold their faulty memorial reconstructions to printers eager to publish a hot script. So, we are told, the 'bad' quartos only give us Shakespeare transmogrified as through an ass's head, and the 'bad' quarto of Merry Wives of Windsor, for example, resembles Shakespeare's Wives only as much as Bottom the Weaver's play of Pyramus and Thisbe resembles Ovid's original or Golding's translation. There is a six-foot shelf of monographs, essays and textual notes exclaiming over the worthlessness, the essential unShakespearean-ness, of these 'bad' quartos.

Well, having come to the study of Shakespeare with an ass's head installed as original equipment, I have taken to reading these 'bad' quartos. Like Bottom I have had a most rare vision that I will share with you. My Bottomless dream is that the 'bad' texts are not non-Shakespearean but rather very early Shakespearean, and that we can learn wonders about dramatic technique and Shakespeare's artistry by looking for the differences between these earliest scripts and their later versions. I propose a kind of differential calculus of theatrical variants, a systematic study of alternative forms of gesture and movement to supplement our already vigorous studies applied to the modes of purely verbal expression in dramatic characters.

From among the many possible examples of differential gestures I might analyse, I've chosen variants found in the roles of three young women: from the histories, Queen Margaret in two versions of the second and third parts of Henry VI, from the comedies Anne Page in the Quarto and Folio texts of Merry Wives of Windsor, and from the tragedies Juliet in equivalent moments as shown in the first and second Quartos of Romeo and Juliet. We will see that in each case either alternative version of a specific gesture or movement will 'work' onstage and be recognized as meaningful by a theatrical audience. We may find, though, that the alternatives may not be imagined with equal ease by readers - including many editors of the plays - who are untrained in the interpretation of theatrical scripts. And, incidentally, we may note that either of the alternatives would be accepted unquestionably as 'Shakespearean' if it were the only one we had.

First Queen Margaret. In the opening scene of the 1594 text of 2 Henry VI, at the first meeting with her husband the king, Margaret presents herself by self-consciously announcing her own modesty and tender spirit [in my italics, marked (A) and (B)]: 
The fairest Queene that euer King possest.

KING. Suffolke arise.

Welcome Queene Margaret to English Henries Court,

The greatest shew of kindnesse yet we can bestow,

Is this kinde kisse: Oh gracious God of heauen,

Lend me a heart repleat with thankfulnesse,

For in this beautious face thou hast bestowde

A world of pleasures to my perplexed soule.

QUEENE. Th'excessiue loue I beare vnto your grace,

Forbids me to be lauish of my tongue,

Least I should speake more then beseemes a woman:

Let this suffice, my blisse is in your liking,

And nothing can make poore Margaret miserable,

Vnlesse the frowne of mightie Englands King.

KIN. Her lookes did wound, but now her speech doth pierce,

Louely Queene Margaret sit by my side:

And vnckle Gloster and you Lordly Peeres,

With one voice welcome my beloued Queene.

ALL. Long liue Queene Margaret, Englands happinesse.

QUEENE. We thank you all.

Sound Trumpets.

2 Henry VI.

Quarto (1594), A2v ; 1.1.16-38

Her bridegroom invites her to sit beside him [at (C)], and as far as we can tell she sits. Then the nobles of England greet the new queen while they stand about the royal thrones [(D)]. Margaret's first moments on stage stress decorum, acquiescence to her husband's will, and a posture of repose (albeit formal) within a surrounding context of attentive but upright peers of the realm.

The same moment in the second script of this play, published in the 1623 First Folio, has Queen Margaret announce her boldness rather than her modesty [in my italics, at mark (a)].

The Fairest Queene, that euer King receiu'd.

KING. Suffolk arise. Welcome Queene Margaret,

I can expresse no kinder signe of Loue

Then this kinde kisse: $O$ Lord, that lends me life,

Lend me a heart repleate with thankfulnesse:

For thou hast giuen me in this beauteous Face

A world of earthly blessings to my soule,

If Simpathy of Loue vnite our thoughts.

QUEEN. Great King of England, \& my gracious Lord,

The mutuall conference that my mind hath had,

By day, by night; waking, and in my dreames,

In Courtly company, or at my Beades,

With you mine Alder liefest Soueraigne,

Makes me the bolder to salute my King,

With ruder termes, such as my wit affoords, 
And ouer ioy of heart doth minister.

KING. Her sight did rauish, but her grace in Speech,

Her words yclad with wisedomes Maiesty,

Makes me from Wondring, fall to Weeping ioyes,

Such is the Fulnesse of my hearts content.

Lords, with one cheerefull voice, Welcome my Loue.

ALL KNEEL. Long liue Qu. Margaret, Englands happines.

QUEEN. We thanke you all.

Florish

Folio (1623), TLN 23-45

Instead of sitting while the nobles salute the Queen, the Folio has Margaret and Henry standing while everyone else onstage kneels before them [at (b)]. Pride of place and dominance become the significant motives made visible to the audience.

Later in the play we have another example of variant gesture affecting the characterization of Margaret. A group of commoners with written petitions appealing for help from Duke Humphrey, the Protector of the Kingdom, inadvertently approach Queen Margaret and her paramour, the Duke of Suffolk. In the earlier text Suffolk reads the petition against his own actions, tears it to pieces, and drives the petitioners away [at my italics, marked (A)]

SUFFOLKE. I marry this is something like,

Whose within here?

Enter one or two.

Sirra take in this fellow and keepe him close,

And send out a Purseuant for his maister straight,

Weele here more of this before the Kind.

Exet with the Armourers man.

Now sir what yours? Let me see it,

Whats here?

A complaint against the Duke of Suffolke for enclosing the commons of long Melford.

How now sir knaue.

1 PET. I beseech your grace to pardon me, me, I am but a

Messenger for the whole town-ship.

He teares the papers.

SUFFOLKE. So now show your petitions to Duke Humphrey.

Villaines get you gone and come not neare the Court,

Dare these pesants write against me thus.

Exet Petitioners.

QUEENE. My Lord of Suffolke, you may see by this,

The Commons Joues vnto that haughtie Duke,

Quarto, B2v $; 1$.3.19-43

[my italics]

Suffolk's response is angry and instantaneous, an explosion of irritation. 
The equivalent in the Folio has Suffolk again read the petition [at section bracketed and marked (a)], but then, after a delay of five speeches during which a different suit is dealt with, Queen Margaret tears the papers in what seems to be a meditated action [at (b)].

SUFF. Thy Wise too? that's some Wrong indeede, What's yours? What's heere? Against the Duke of Suffolke, for enclosing the Commons of Melforde. How now, Sir Knaue?

2 PET. Alas Sir, I am but a poore Petitioner of our whole Towneship.

PETER. Against my Master Thomas Horner, for saying, That the Duke of Yorke was rightfull Heire to the Crowne.

QUEENE. What say'st thou? Did the Duke of Yorke say, hee was rightfull Heire to the Crowne?

PETER. That my Mistresse was? No forsooth: my Master said, That he was, and that the King was an Vsurper.

SUFF. Who is there?

Enter Seruant.

Take this fellow in, and send for his Master with a Purseuant presently: wee'le heare more of your matter before the King.

$$
\text { Exit. }
$$

QUEENE. And as for you that loue to be protected

Vnder the Wings of our Protectors Grace,

Begin your Suites anew, and sue to him.

Teare the Supplication

Away, base Cullions: Suffolke let them goe.

ALL. Come, let's be gone.

QUEENE. My Lord of Suffolke, say, is this the guise?

Exit

Is this the $\mathrm{F}$ ashions in the Court of England?

Folio, TLN 404-29 [my italics]

She, not Suffolk, orders the petitioners away [at (c)], and she further commands Suffolk to let them pass from the stage [at(d)]. Here as in the opening scene of the play variant gesture shows Margaret dominating the stage with aggressive strength.

A third variant occurs at the opening of a scene showing the court returning from a hunt with falcons.

Enter the King and Queene with her Hawke on her fist, and Duke Humphrey and Suffolke, and the Cardinall, as if they came from hawking. QUEENE. My Lord, how did your grace like this last flight?

But as I cast her off the winde did rise, And twas ten to one, old Ione had not gone out.

KING. How wonderfull the Lords workes are on earth, Euen in these silly creatures of his hands, Vnckle Gloster, how hie your Hawke did sore? And on a sodaine soust the Partridge downe.

Quarto. C1 ${ }^{\mathrm{v}} ; 2$ 2.1.1-8

[my italics] 
The Quarto text has Margaret address the opening speech directly to her husband [at (A)]. While she speaks she draws attention almost deferentially towards his response. Because she faces the king and has asked him a question needing a reply, Henry functions for the moment as the dominant figure in the group even though Margaret is the one who is speaking.

But the Folio equivalent makes Margaret and her own excitement the centre of attention for all eyes [my italics, at (a)].

Enter the King, Queene, Protector, Cardinall, and Suffolke, with Faulkners hallowing.

QUEENE. Beleeue me Lords, for flying at the Brooke,

I saw no better sport these seuen yeeres day:

Yet by your leaue, the Winde was very high,

And ten to one, old Ioane had not gone out.

KING. But what a point, my Lord, your Faulcon made,

And what a pytch she flew aboue the rest:

To see how God in all his Creatures workes,

Yea Man and Mirds are fayne of climbing high.

Folio, TLN 715-24.

In acting terms, by addressing everyone in the group at once she 'takes the stage.' She makes herself the most important figure. We may not have a specified movement of a hand or leg, but the manifold gestures appropriate to the message 'Look at me!' are among those learned earliest in our childhood (especially memorized by those of us destined to become actors, even by some fated for the profession of teaching).

One last example from Margaret, this one found in the third part of Henry VI. The Queen arrives at the court of the King of France as a powerless fugitive seeking his help.

Enter king Lewis and the ladie Bona, and Queene Margaret, Prince Edward, and Oxford and others.

LEWIS. Welcome Queene Margaret to the Court of France,

It fits not Lewis to sit while thou dost stand,

Sit by my side, and here I vow to thee,

Thou shalt haue aide to repossesse thy right,

And beat proud Edward from his vsurped seat,

And place king Henry in his former rule.

QUEEN. I humblie thanke your royall maiestie,

And pray the God of heauen to blesse thy state,

Great king of France, that thus regards our wrongs.

3 Henry VI. Q1 (an octavo volume, 1595),

C8v; 3.3.1-16

[my italics]

In a direct recapitulation of the image of her arrival as a bridge in the 
court of England, we see the King of France invite her to sit down beside him. Like the earlier moment in the first version of 2 Henry VI Margaret simply joins the royal figure on a throne or a chair of state. And like the Folio version of the earlier scene, in the Folio text here Margaret instead has a bolder visual gesture:

Flourish. Enter Lewis the French King, his Sister Bona, his Admirall, call'd Bourbon: Prince Edward, Queene Margaret, and the Earle of Oxford. Lewis sits, and riseth up againe.

LEWIS. Faire Queene of England, worthy Margaret,

Sit downe with vs: it ill befits thy State,

And Birth, that thou should'st stand, while Lewis doth sit.

MARG. No, mightie King of France: now Margaret

Must strike her sayle, and learne a while to serue,

Where Kings command. I was (I must confesse)

Great Albions Queene, in former Golden dayes:

But now mischance hath trod my Title down,

And with dis-honor layd me on the ground,

Where I must take like Seat vnto my fortune,

And to my humble Seat conforme my selfe.

LEWIS. Why say, faire Queene, whence springs this deepe despaire?

MARG. From such a cause, as fills mine eyes with teares,

And stops my tongue, while heart is drown'd in cares.

LEWIS. What ere it be, be thou still like thy selfe,

And sit thee by our side.

Seats her by him.

Folio, TLN 1720-41 [my italics]

She refuses Lewis's offer and sits down on the stage floor, 'on the ground, / Where I must take like Seat unto my fortune, / And to my humble Seat conforme my selfe.' Lewis reacts to her move with great sympathy [at (c)]. (For a royal person, sitting on the bare earth was a conventional gesture of grave despair: Constance in King John [TLN 990-6; II.iv.114], Richard II ['For Gods sake let us sit upon the ground,' F 2v, III.ii.155], and King Lear, in the Quarto text of III.ii.42 which reads 'Alas sir, sit you here?' [F4].) Margaret's daring action draws our eyes to her; she is an arresting presence even in her moments of political weakness. The king eventually raises her to sit beside him at [at (d)]: the thirteen-line interval between his first offer and her acceptance forms a kind of gestural arpeggio, a jazz riff played with the simple action of taking a seat.

I chose these four moments from among hundreds of textual variants relating to Margaret's role in the two versions of the Henry VI plays. Now I may be wrong about just who was responsible for these variants. Evidence gets distorted and filtered passing through an ass's head. But whoever set up one or both of these alternative versions, in whatever 
order they may have been generated and printed, the alternative texts certainly seem to merit our close attention as records of theatrical gesture, Shakespearean or not.

I would like to look briefly at two further examples of similar character changes related to gestures in other plays. These are more speculative, bringing into play my own personal interpretations, more open to dispute. I chose these moments though because I feel they show us a basic quality of Shakespearean characterization, a building-in of multiplylayered personality typically Shakespearean where other playwrights would settle for more broadly outlined patterns of psychological and physical behaviour.

The first of these character variants is found in Merry Wives of Windsor when the young gentleman Master Fenton announces his love to Anne Page, asking her to marry him.

Enter M. Fenton, Page, and mistresse Quickly.

FEN: Tell me sweet Nan, how doest thou yet resolue,

Shall foolish Slender haue thee to his wife?

Or one as wife as he, the learned Doctor?

Shall such as they enioy thy maiden hart?

Thou knowst that I haue alwaies loued thee deare, And thou hast oft times swore the like to me.

AN: Good M. Fenton, you may assure your selfe My hart is setled vpon none but you,

Tis as my father and mother please:

Get their consent, you quickly shall haue mine.

FEN: Thy father thinks I loue thee for his wealth,

Tho I must needs confesse at first that drew me,

But since thy vertues wiped that trash away,

I loue thee Nana, for so deare is it set,

That whilst I liue, I nere shall thee forget.

[QUICKLY.] Godes pitie here comes her father.

Enter M. Page, his wife, M. Shallow, and Slender.

PA: M. Fenton I pray what make you here?

You know my answere sir, shees not for you:

Knowing my vow, to blame to vse me thus.

FEN: But heare me speake sir.

PA: Pray sir get you gon: Come hither daughter,

Sonne Slender let me speak with you. (they whisper)

QUIC: Speake to Misteris Page.

FEN. Pray misteris Page let me haue your consent.

MIS. PA. Ifaith M. Fenton tis as my husband please.

For my part Ile neither hinder you, nor further you.

QUIC. How say you this was my doings?

I bid you speake to misteris Page.

FEN. Here nurse, theres a brace of angels to drink,

Worke what thou canst for em, farwell.

(Exit Fen.) 
QUIC. By my troth so I will, good hart.

PA. Come wife, you an I will in, weele leaue M. Slender

And my daughter to talke together. M. Shallow,

You may stay sir if you please.

Exit Page and his wife.

SHAL. Mary I thanke you for that:

To her cousin, to her.

SLEN. Ifaith I know not what to say.

AN. Now M. Slender, whats your will?

SLEN. Godeso theres a Iest indeed: why misteris An,

I neuer made wil yet: I thank God I am wise inough for that.

SHAL. Fie cusse fie, thou art not right,

$O$ thou hadst a father.

SLEN. I had a father misteris Anne, good vncle

Tell the Iest how my father stole the goose out of

The henloft. All this is nought, harke you mistresse Anne.

SHAL. He will make you ioynter of three hundred pound a year, he shall make you a Gentlewoman.

SLEN. I be God that I vill, come cut a long taile, as good as any is in Glostershire, vnder the degree of a Squire.

AN. O God how many grosse faults are hid,

And covered in three hundred pound a yeare?

Well M. Slender, within a day or two Ile tell you more.

SLEND. I thank you good misteris Anne, vncle I shall haue her.

QUIC. M. Shallow, M. Page would pray you to come you, and you M.

Slender, and you Mistris An.

SLEND. Well Nurse, if youle speake for me,

Ile giue you more then Ile talke of.

Exit omnes but Quickly.

QUIC. Indeed I will, Ile speake what I can for you,

But specially for M. Fenton:

But specially of all for my Maister,

And indeed I will do what I can for them all three.

Exit

Merry Wives of Windsor

Quarto (1602), E4, E4v , F1; 3.4.1-111

[my italics]

In the Quarto text Fenton is the more sophisticated member of the pair. He teases Anne Page about her other suitors [at (A)]. She is direct and guileless, like an ostentatiously sincere Arcadian shepherdess [(B)]. Throughout the rest of the scene in the Quarto, specific dialoguecommands direct characters to move about the stage forming little whispering groups [marked 1,2,3,4,5]. 'Come hither daughter, Sonne Slender let me speak with you,' says Master Page; 'Speake to Misteris Page,' says Quickly to Fenton; and Shallow urges Slender 'To her cousin, to her.' Notice how in the Quarto almost everyone except for Anne Page and Fenton gives commands that move others around the stage, and with the exception of Fenton (who stays even after Master Page orders him 
away) the orders are followed; those commanded go where they are sent.

The Folio presents different actions and very different characteristics for the dramatis personae, though essentially the same narrative material is covered.

Enter Fenton, Anne, Page, Shallow, Slender, Quickly, Page, Mist. Page.

FEN. I see I cannot get thy Fathers loue,

Therefore no more turne me to him (sweet Nan.)

ANNE. Alas, how then?

FEN. Why thou must be thy selfe.

He doth obiect, I am too great of birth,

And that my state being gall'd with my expence,

I seeke to heale it onely by his wealth.

Besides these, other barres he layes before me,

My Riots past, my wilde Societies,

And tels me 'tis a thing impossible

I should loue thee, but as a property.

AN. May be he tels you true.

[FEN.] No, heauen so speed me in my time to come,

Albeit I will confesse, thy Fathers wealth

Was the first motiue that I woo'd thee (Anne:)

Yet wooing thee, I found thee of more valew

Then stampes in Gold, or summes in sealed bagges:

And 'tis the very riches of thy selfe,

That now I ayme at.

AN. Gentle M. Fenton,

Yet seeke my Fathers loue, still seeke it sir,

If opportunity and humblest suite

Cannot attine it, why then harke you hither

SHAL. Breake their talke Mistris Quickly,

My Kinsman shall speake for himselfe.

SLEN. Ile make a shaft or a bolt on't, slid, tis but venturing.

SHAL. Be not dismaid.

SLEN. No, she shall not dismay me:

I care not for that, but that I am affeard.

QUI. Har ye, M. Slender would speak a word with you.

AN. I come to him. This is my Fathers choice:

$O$ what a world of vilde ill-fauour'd faults

Lookes hadsome in three hundred pounds a yeere?

QUI. And how do's good Master Fenton?

Pray you a word with you.

SHAL. Shee's comming; to her Coz:

$O$ boy, thou hadst a father.

SLEN. I had a fahter (M. An) my vncle can tel you good iests of him: pray you Vncle, tel Mist. Anne the iest how my Father stole two Geese out of a Pen, good Vnckle.

SHAL. Mistris Anne, my Cozen loues you.

SLEN. I that I do, as well as I loue any woman in Glocestershire.

SHAL. He will maintaine you like a Gentlewoman. 
SLEN. I that I will, come cut and long-taile, vnder the degree of a Squire.

SHAL. He will make you a hundred and fiftie pounds ioynture.

ANNE. Good Maister Shallow let him woo for himselfe.

SHAL. Marrie I thank you for it: I thank you for that good comfort: she cals you (Coz) Ile leaue you.

ANNE. Now Master Slender.

SLEN. Now good Mistris Anne.

ANNE. What is your will?

SLEN. My will? Odd's-hart-lings, that' a a prettie iest indeede: I ne're made my Will yet (I thanke Heauen:) I am not such a fickely creature, I giue Heauen praise.

ANNE. I meane (M. Slender) what wold you with me?

SLEN. Truely, for mine owne part, I would little or nothing with you: your father and my vncle hath made motions: if it be my lucke, so; if not, happy man bee his dole, they can tell you how things go, better then I can: you may aske your father, heere he comes.

PAGE. Now Mr Slender; Loue him daughter Anne.

Why how now? What does Mr Fenter here?

You wrong me Sir, thus still to haunt my house.

I told you Sir, my daughter is disposd of.

FEN. Nay Mr Page, be not impatient.

MIST. PAGE. Good M. Fenton, come not to my child.

PAGE. She is no match for you.

FEN. Sir, will you heare me?

PAGE. No, good M. Fenton.

Come M. Shallow: Come sonne Slender, in;

Knowing my minde, you wrong me (M. Fenton.)

QUI. Speake to Mistris Page.

FEN. Good Mist. Page, for that I loue your daughter

In such a righteous fashion as I do,

Perforce, against all checkes, rebukes, and manners,

I must aduance the colours of my loue,

And not retire. Let me haue your good will.

AN. Good mother, do not marry me to yond foole.

MIST. PAGE. I meane it not, I seeke you a better husband.

QUI. That's my master, M. Doctor.

AN. Alas I had rather be set quick i'th earth,

And bowl'd to death with Turnips.

MIST. PAGE. Come, trouble not your selfe good M.

Fenton, I will not be your friend, nor enemy:

My daughter will I question how she loues you,

And as I finde her, so am I affected:

Till then, farewell Sir, she must needs go in,

(VIII)

Her father will be angry.

FEN. Farewell gentle Mistris: farewell Nan.

QUI. This is my doing now: Nay, saide I, will you cast away your childe on

a Foole, and a Physitian: Looke on M. Fenton, this is my doing.

FEN. I thanke thee: and I pray thee once to night,

Giue my sweet Nan this Ring: there's for thy paines.

QUI. Now heauen send thee good fortune, a kinde heart he hath: a woman 
would run through fire \& water for such a kinde heart. But yet, I would my Maister had Mistris Anne, or I would M. Slender had her: or (in sooth) I would M. Fenton had her; I will do what I can for them all three, for so I haue promisd, and Ile bee as good as my work, but speciously for M. Fenton. Well, I must of another errand to Sir Iohn Falstaffe from my two Mistresses: what a beast am I to slacke it.

\section{Exeunt.}

Merry Wives of Windsor.

Folio, TLN 1567-1677. [my italics]

Fenton professes his sincerity, beseeching Anne like a simple shepherd, and Anne Page turns the tables on him. She teases Fenton as the more sophisticated, joking and courtious lover $[(a),(b),(c)]$. The gesture only in the Folio is necessary when Anne breaks the monopoly of movecommands. Beckoning Fenton to move with her out of hearing of Quickly, Shallow and Slender, she proposes the first tête-à-tête in the scene [(I)], and later she drives Shallow away so than she may speak with Slender alone $[(\mathrm{V})]$. (Commands and obedience to commands don't follow the same authoritarian patterns found in the Quarto.) Through her commandsfor-actions and gestures associated with them, Anne Page takes on visible authority as an effective, active person unlike the will-less persona of her Quarto equivalent.

These variants cohere with scores of others elsewhere in Merry Wives. Similar kinds of changes occur in the roles of Mistress Ford, Mistress Page, the Host of the Garter and, most of all, Sir John Falstaff and Master Ford.

Finally one last variant design for a gesture in one more young woman's role. In the third scene of Romeo and Juliet Lady Capulet tells her daughter about the offer of marriage she has received from the County Paris.

WIFE: And that same marriage Nurce, is the Theame I meant to talke of: Tell me Iuliet, howe stand you affected to be married?

IUL: It is an honor that I dreame not off.

NURCE: An honor! were not I thy onely Nurce, I would say thou hadst suckt wisedome from thy Teat.

WIFE: Well girle, the Noble Countie Paris seekes thee for a Wife.

NURCE. A man young Ladie, Ladie such a man as all the world, why he is a man of waxe.

WIFE: Veronaes Summer hath not such a flower.

NURCE: Nay he is a flower, in faith a very flower.

WIFE: Well Iuliet, how like you of Paris loue.

IULIET: Ile looke to like, if looking liking moue,

But no more deepe will I engage mine eye,

Then your consent giues strength to make it flie.

Enter Clowne.

CLOWNE: Madilam you are cald for; supper is readie, the Nurce curst in 
the Pantrie, all thinges in extreamitie, make hast for I must be gone to waite.

Romeo and Juliet.

Q1 (1597), B4v-C1; 1.3.63-105.

In the 1597 First Quarto Lady Capulet and the Nurse briefly commend Paris [at (A)], and Juliet very tentatively responds to the idea of marriage [(B)]. Then a servant enters with urgent calls to hurry the exit of the Lady and the Nurse, and as far as we can tell from the script the three women quickly go out together [(C)]. Note that Juliet's mother merely broaches the ideas of marriage and Paris's attractiveness is single short speeches, and she says nothing at all about the blessed state of matrimony.

The 1599 Second Quarto offers a different constellation of motives and forces underlying the action.

OLD LA. Marrie, that marrie is the very theame

I came to talke of, tell me daughter Iuliet,

How stands your dispositions to be married?

IULIET. It is an houre that I dreame not of.

NURSE. An houre, were not I thine onely Nurse, I would say thou hadst suckt wisedome from thy teate.

OLD LA. Well thinke of marriage now, yonger then you

Here in Verona, Ladies of esteeme,

Are made alreadie mothers by my count.

I was your mother, much vpon these yeares

That you are now a maide, thus then in briefe:

The valiant Paris seekes you for his loue.

NURSE. A man young Lady, Lady, such a man as all the wold. Why hees a man of waxe.

OLD LA. Veronas Sommer hath not such a flower.

NURSE. Nay hees a flower, in faith a very flower.

OLD LA. What say you, can you loue the Gentleman?

This night you shall behold him at our feast,

Reade ore the volume of young Paris face,

and find delight, writ there with bewties pen,

Examine euery married liniament,

And see how one an other lends content:

And what obscurde in this faire volume lies,

Finde written in the margeant of his eyes.

This precious booke of loue, this vnbound louer,

To bewtifie him, onely lacks a Couer.

The fish liues in the sea, and tis much pride

For faire without the faire, within to hide:

That booke in manies eyes doth share the glorie

That in gold claspes locks in the golden storie:

So shall you share all that he doth possesse,

By hauing him, making your selfe no lesse.

NURSE. Lo lesse, nay bigger women grow by men. 
OLD LA. Speake briefly, can you like of Paris loue?

IULI. Ile looke to like, if looking liking moue.

But no more deepe will I endart mine eye,

Then your consent giues strength to make flie.

Enter Serving.

SER. Madam the guests are come, supper seru'd vp, you cald, my young Lady asktfor, the Nurse curst in the Pantrie, and euerie thing in extremitie:

I must hence to wait, I beseech you follow straight.

MO. We follow thee, Iuliet the Countie staies.

NUR. Go gyrle, seeke happie nights to happie days.

Exeunt.

Q2 (1599), B4v'-C1.

[my italics and underlining]

Lady Capulet stresses her status as Juliet's mother and her own superior experience [in the second line and at (a)]. She praises Paris with wild extravagance, concentrating almost exclusively on his physical appearance [at (b)]. And she is short-tempered and pushes repeatedly for an immediate reply [at (II), (III), (IV) and (b)]. Juliet gives the same tentative response, but it stands frailly against a very hard-sell sales pitch. The urgent call from a servant again prompts the exit from the scene, but in this version he also specifically calls for Juliet with the other two women [at (c)].

The gesture that I read in the final moment of the scene is only implied, subtly suggested by the last two speeches. I believe that Lady Capulet and the Nurse have to repeat the servant's commands to Juliet because she hangs back, unwilling to rush into the pressured whirl of courtship, sexuality and marriage proferred by her mother. First the servant calls on her to move, then her mother, and then the Nurse. If Juliet were to leap eagerly toward the exit the last two speeches would be unnecessary. The gesture here is a non-move, a stillness, a hesitant and mute resistance.

Scores of other variants in this text systematically exaggerate the coercive pressures mounted by the Capulets on their daughter. As we saw Anne Page as a more independent character in the second version of Merry Wives, here we see Juliet under tighter constraint, like

a wantons bird,

That lets it hop a litle from his hand,

Like a poore prisoner in his twisted gives,

And with a silken threed, plucks it back againe,

So loving Jealous of his libertie.

[Q2,D4-D4v; II.ii.177-81]

In the balcony scene Juliet feels this constraining love towards Romeo, modelling it on the stresses and forms we can observe in her own destructively-protective familial affections. The tiny gesture of hesitation 
and acquiescence I read in the differential text of this scene reflects the tragic and fundamentally passive helplessness of Juliet's character as it is amplified in the Second Quarto version.

$$
* * * *
$$

As a boy in high school, when I was asked to read Shakespeare's plays I hated the task. They lay dead on the page, or they were mumbled aloud by my hyperesthetic English teacher, and they seemed emotionally bleak, a language expressively so heavy that I could connect them to nothing I had ever known. The words as words and the poetry as poem seemed completely alien. But now, when I teach these playscripts to similarly distanced students, I find that they begin to respond fully when we pay attention to Shakespeare's dialogue as coded action. The movement demanded or simply suggested in the poetry appeals directly to our shared experience as people. The movement makes the poetic action recognizable. The gestural variants I've just examined with you seem to me to demonstrate how Shakespeare probed for more and more compelling and evocative gestures for his actors, hoping, I believe, to create a more binding sympathy between player and audience.

Finally I suggest that a differential calculus of gestural variants is a necessary tool for anyone charged with editing or criticizing Shakespeare's texts. And I offer that a calculus of gesture would go far to open the complex and kinetic phenomena of Shakespeare's plays to the huge audience now exposed to them as opaque school-texts and as cultural icons carved in mute stone.

Hofstra University 